\title{
EMPIRICAL EVIDENCE ON THE LONG-RUN NEUTRALITY HYPOTHESIS USING DIVISIA MONEY
}

\author{
Maggie May-Jean Tang, Chin-Hong Puah* and A.M. Dayang-Affizzah \\ Department of Economics, Faculty of Economics and Business, \\ Universiti Malaysia Sarawak, 94300 Kota Samarahan, Sarawak, Malaysia.
}

\begin{abstract}
By employing Fisher and Seater's (1993) long-run neutrality test, the researchers tested the monetary neutrality proposition in Singapore for the period of 1980-2009. Empirical findings show that monetary neutrality does not hold in Singapore when both the simple-sum money and Divisia money are employed. As both the simplesum and Divisia monetary aggregates are non-neutral, monetary authorities may consider their use as a monetary policy tool affecting real economic activity.
\end{abstract}

Keywords: Monetary Neutrality, Divisia Money, ARIMA Model

\footnotetext{
* Corresponding author: Chin-Hong Puah, Department of Economics, Faculty of Economics and Business, Universiti Malaysia Sarawak, 94300 Kota Samarahan, Sarawak, Malaysia. E-mail: chpuah@ feb.unimas.my
} 